\title{
Analysing the Effect of Supplementing Rumen Protected Choline with Green Tea Extract in Transition Karan Fries Cows
}

\author{
P. Acharya ${ }^{1 *}$, S.S. Lathwal ${ }^{1}$, B. Moharana ${ }^{2}$, N.M. Patnaik ${ }^{3}$ and M. Thul ${ }^{1}$ \\ ${ }^{I}$ Division of Livestock Production Management, NDRI, Karnal, India \\ ${ }^{2}$ Division of Pharmacology, CSIR-CDRI, Lucknow, India \\ ${ }^{3}$ Division of Dairy Extension, NDRI, Karnal, India
}

*Corresponding author

\section{A B S T R A C T}

\section{Keywords}

Rumen protected choline, Green tea extract, Body condition score, Dry matter intake

Article Info

Accepted:

18 January 2019

Available Online:

10 February 2019
The present experiment was carried out on thirty-two pregnant Karan Fries (KF) cows. In control group, cows were fed basal diet. In T1 each cow was fed rumen protected choline (RPC) (55g/day), in T2 - green tea extract (GTE) $(3 \mathrm{~g} / \mathrm{d})$ and in T3-RPC + GTE $(55+3) \mathrm{g}$ /day along with basal diet. The duration of experiment was 30 days before calving to 60 days after parturition. Animals were evaluated on average body weights, body condition score (BCS) and dry matter intake (DMI). The fortnightly average body weights, BCS and DMI did not differ significantly $(p \geq 0.05)$ across the groups. In conclusion, feeding of RPC and GTE in combination did not affect the palatability and digestibility of the feed, for which it can be added in the feed formulation for better performance.

\section{Introduction}

High-yielding dairy cows enter a state of negative energy balance (NEB) around calving when the energy demand for maintenance and lactation exceeds that of dietary energy intake (Bauman and Currie, 1980). Cows with excessive body tissue mobilisation at this stage may take up to 20 weeks to regain a positive energy balance status (Taylor et al., 2004). At the same time, dairy cows show a marked decrease in dry matter intake (DMI) that is related to physical, behavioural, metabolic and hormonal changes around parturition
(Grummer et al., 2008). Previous authors found that, there was decrease of about 30 percent in DMI during the transition period (Bertics et al., 1992; Hayirli et al., 1998; Robinson and Garrett, 1999). After 3 weeks of calving, DMI increases at the rate of 1.5 to $2.5 \mathrm{~kg}$ per week (Grant and Albright, 1995) and this increase is more rapid in multiparous cows than primiparous cows (Kertz et al., 1991; Robinson and Garrett, 1999). The reason behind decrease in DMI during pre partum period is growing foetal size occupying abdominal space and displacing rumen volume. 
Choline is very much required to brain and neuromuscular signalling. Phosphatidyl choline, derived from choline, is associated with intracellular transmission and is an integral constituent of all cell membranes and is a source of methyl groups for transmethylation reactions. Responses in DMI with the feeding of rumen protected choline (RPC) have been variable. Some researchers reported no significant effects of RPC supplementation on DMI in periparturient cows (Erdman and Sharma, 1991; Hartwell et al., 2000; Piepenbrink and Overton, 2003; Zahra et al., 2006; Davidson et al., 2008; Elek et al., 2008; Sheikh et al., 2014). Conversely, other workers reported (Oelrichs et al., 2004; Chung et al., 2005; Ardalan et al., 2010) marked increase in DMI in RPC supplemented cows during transition phase. The mechanism by which choline might influence DMI is not understood, but it is plausible to speculate an indirect effect mediated by improved post parturient health. No treatment effects of RPC for body weight and BCS were observed by other workers (Zom et al., 2011; Zahra et al., 2006).

Green tea, made from the leaves of Camellia sinensis, is a historically popular drink across the world. The green-tea catechins include catechin (C), (2)-epicatechin (EC), (2)epigallocatechin (EGC), (2)-epicatechin-3gallate (ECG), and (2)-epigallocatechin-3gallate (EGCG). Out of these, EGCG is a predominant catechin, and has several biological and pharmacological properties (Hodgson et al., 2013). Many researches demonstrated that dietary green tea supplementation tended to increase the overall average weight gain and feed intake of goats, pigs etc. (Ahmed et al., 2015; Tan et al., 2011; Hossain et al., 2012), in contrast, Sayama et al., (2000) and Kaneko et al., (2001) reported reduced body weight and weight gain in rats and broilers.
With this backdrop, being envisaged with the aim, the present study has been designed to study the 'effect of supplementation of rumen protected choline (RPC) and green tea extract (GTE) on average body weights, body condition score (BCS) and dry matter intake (DMI).

\section{Materials and Methods}

\section{Location of experiment}

The study was conducted in the experimental cattle shed of National Dairy Research Institute (NDRI), Karnal, India. The sample analysis was done in Feed Processing and Quality Control Laboratory and Precisition Instrument Laboratory of Dairy Cattle Nutrition Division, NDRI, Karnal.

\section{Procurement of rumen protected choline (RPC) and green tea extract}

The RPC, in the form of encapsulation with fatty acids and prepared by spray freeze drying technology, was purchased from Kemin animal nutrition, India. The green tea extract (GTE), an aqueous extract, was purchased from Sarthak Herbs, Karnal, India.

\section{Ethical permission}

The experiment was approved by the Institutional Animal Ethical Committee (IAEC) of Indian Council of Agricultural Research (ICAR) - National Dairy Research Institute (NDRI) constituted as per article 13 of the CPCSEA rules, laid down by the Govt. of India (Regd no-1705/GO/al/13 CPCSEA) dated 3/7/2013. All the ethical guidelines were followed during the course of the experiment.

\section{Experiment}

Thirty two pregnant dairy cows in second to fourth lactation with most probable 
production ability (MPPA) of around $4000 \mathrm{~L}$ milk production were selected from the herd, maintained at Cattle Yard, NDRI, Karnal.

Their requirements were fulfilled by feeding concentrate mixture, green fodder (sorghum, maize, oats, sugar graze) and dry roughage (wheat straw) based on National Research Council (NRC, 2001), USA recommendations.

The experimental groups and supplementation of RPC and GTE were as follows.

GroupsFeeding schedule

Control Basal diet without supplementation (ICAR Feeding standard)

Treatment 1 Basal diet with Rumen Protected Choline (RPC) (55 gram/day)

Treatment 2 Basal diet with Green Tea Extract (GTE) (3 gram /day)

Treatment 3 Basal diet with RPC (55 gram/day) + GTE (3 gram /day)

The animals were put on the experiment around 37 days before expected date of parturition and given adaptation period of seven days. The duration of experiment was 30 days before calving to 60 days after parturition. Total duration of the experiment was 90 days.

\section{Observations recorded during study}

\section{Body Weight}

Body weight of the animals was recorded at fortnight interval using computerized weight management system from Leotronic Scales Pvt. Ltd. The maximum capacity of the system was $1500 \mathrm{~kg}$ and minimum capacity of $4 \mathrm{~kg}$, the error was $\pm 200 \mathrm{~g}$. The animals were weighed for two consecutive days in the morning before offering feed and water. The average body weight of two days was considered as body weight for that fortnight.

\section{Body Condition Score (BCS)}

For recording the body condition of the animals, following points were taken into account:

Vertebral column (chine, lion and rump) flesh covering at the spinous processes of these regions.

Spinous processes: their prominence and sharpness.

Tail head region: prominence of depression between backbone and pins and between pin and hook bones.

Ribs: their flesh covering.

Considering the above points, NRC (2001) presented a score chart, which was adopted in the present study. The cows of control and experimental groups were body condition scored on every fortnight up to parturition.

\section{Dry matter intake}

Daily DM intake was observed by recording the daily feed offered and residue for 90 days. The DM of different feed ingredients was recorded weekly.

\section{Statistical analysis}

Analysis of data was carried out using oneway analysis of variance (ANOVA) to interpret the effect of dietary treatments on various parameters (GRAPHPAD PRISM software) and presented as mean \pm SE. Values of $p \leq 0.05$ were considered significant. 


\section{Results and Discussion}

\section{Body weight}

The fortnightly average body weights, in different groups are presented in Table 1. The body weights $(\mathrm{kg})$, varied from $439.00 \pm$ 23.25 to $381.12 \pm 22.84$ in control, $442.62 \pm$ 21.74 to $395.37 \pm 23.01$ in $\mathrm{T} 1,440.12 \pm$ 23.97 to $392.63 \pm 23.38$ in $\mathrm{T} 2$ and $444.25 \pm$ 29.20 to $390.50 \pm 27.71$ in $\mathrm{T} 3$. Body weights at fortnight interval did not differ significantly ( $p \geq 0.05)$ across the groups.

Erdman and Sharma (1991) also did not notice any significant effect of feeding protected choline on body weight changes during early lactation. Piepenbrink and Overton (2003) observed that body weights did not differ significantly $(p \geq 0.05)$ by feeding of RPC to lactating cows (45, 60 and $75 \mathrm{~g}$ RPC/d). In one experiment, (Zom et al., 2011) cows were fed $60 \mathrm{~g}$ of RPC, 3 weeks before and 6 weeks after calving and no significant difference was observed in body weight $(\mathrm{p} \geq 0.05)$. However, Pandurang, (2012) found significant difference on body weight $(p \leq 0.05)$ when transition KF cows were fed $54 \mathrm{~g}$ of RPC for 120 days. Conversely, Hartwell et al., (2000) observed that periparturient cows fed $12 \mathrm{~g}$ of $\mathrm{RPC} / \mathrm{d}$, had greater BW loss than did cows fed 0 or 6 $\mathrm{g} / \mathrm{d}$.

There is a scarcity of reports on effect of green tea extract on body weight of cows in transition period. Tan et al., (2011) reported increased average daily gain in goats supplemented with green tea catechin components. Hossain et al., (2012) reported increased weight gain when $2.0 \%$ green tea byproduct was fed to finishing pigs and the reason for increased weight gain was attributed to the presence of high concentration of catechins, acting as a growth promoter for the intestinal and ruminal micro- organisms leading to higher nutrient digestion (Tan et al., 2011). In contrast, Sayama et al., (2000) and Kaneko et al., (2001) reported reduced body weight and weight gain in rats and broilers when different levels of green tea were provided with basal diets, which may be due to the presence of high level of tannin in green tea.

However, in our case, we didn't found any significant difference between control and all treatments which indicates that treatments were able to increase the performances without causing any negative effect on weight gain.

\section{Body Condition Score (BCS)}

The fortnightly average BCS, in different groups are presented in Table 2. The BCS, across the groups, ranged from $3.62 \pm 0.12$ to $3.06 \pm 0.14$ in control, $3.68 \pm 0.13$ to $3.18 \pm$ 0.13 in $\mathrm{T} 1,3.62 \pm 0.08$ to $3.12 \pm 0.12$ in $\mathrm{T} 2$ and $3.60 \pm 0.13$ to $3.17 \pm 0.08$ in $\mathrm{T} 3$ without any significant difference $(\mathrm{p} \geq 0.05)$.

BCS is a logistic tool for assessment of nutritional status of animal and their management for optimal performance. The maintenance of an optimal body condition score relative to lactation stage, milk yield, nutrition and health status is perhaps the most important aspect of dairy cow management that facilitates a healthy transition from pregnancy to lactation. Condition loss indicates intensive mobilization of body tissue (mostly fat) during the first few weeks of lactation (Bell et al., 1995; Hartwell et al., 2000). The non-significant effect of RPC on BCS change in this study is in agreement with the results reported by Hartwell et al., (2000). Hartwell et al., (2000) observed that when periparturient cows were fed 6 and $12 \mathrm{~g}$ $\mathrm{RPC} / \mathrm{d}$, total BCS loss was not affected by treatment. Piepenbrink and Overton (2003) also reported no effect of feeding RPC (19 
g/d) on BW or BCS. Similar results were also observed by other workers (Janovick et al., 2006; Davidson et al., 2008 and Elek et al., 2008). BCS at calving is also a reliable indicator of reproductive performance (Baruselli et al., 2001). Cows that are having high body condition score at calving or those losing excess body weight are more likely to have a prolonged interval to first oestrus; thereby prolonging days open (Roche, 2006). Major increases in or loss of BCS has been found to be undesirable. The optimum reproductive efficiency has been observed when BCS loss was at or below 0.5 units during the transition period (Roche, 2006).

In our result we found that supplementing RPC and GTE did not cause any deleterious effects affecting body condition.

\section{Dry Matter Intake (DMI)}

The fortnight average DMI, in different groups is presented in Table 3. The DMI varied from $11.06 \pm 0.29$ to $13.46 \pm 0.39$ in Control, $11.18 \pm 0.29$ to $13.75 \pm 0.28$ in $\mathrm{T} 1$, $10.93 \pm 0.25$ to $13.87 \pm 0.39$ in $\mathrm{T} 2$ and 11.12 \pm 0.37 to $14.08 \pm 0.26$ in $\mathrm{T} 3$. There was no significant difference between groups in terms of DMI.

Few research studies have found significant effect of dietary RPC on DMI of dairy cows. de Ondarza et al., (2007) obtained a decrease $(\mathrm{P}<0.05)$ in DMI in a commercial herd when feeding as little as $3.1 \mathrm{~g} / \mathrm{d}$ of RPC over a 4-wk period. In a study by Zahra et al., (2006), DMI was increased during the period $3 \mathrm{wk}$ prepartum through 4 wk postpartum with 14 $\mathrm{g} / \mathrm{d}$ of dietary RPC supplementation in fat (BCS $\geq 4,3$ wk before calving) cows, with no response found in non fat cows. Intake of 282 $\mathrm{g} / \mathrm{d}$ of unprotected choline chloride decreased DMI, with no effect found at an intake level of $159 \mathrm{~g} / \mathrm{d}$ (Sharma and Erdman, 1988). Davidson et al., (2008) found no significant difference $(\mathrm{P}<0.01)$ in DMI compared to control when RPMet and RPC was fed at @ 20 and $40 \mathrm{~g} / \mathrm{d}$ respectively in multiparous dairy cattle. Elek et al., (2008) found no significant difference in prepartum (12.4 vs. $12.5 \mathrm{~kg} /$ day) and postpartum (23.7 vs. 24.1 $\mathrm{kg} /$ day) DMI in dairy animals when fed 100 $\mathrm{g} / \mathrm{d}$ (21 days before parturition) and $200 \mathrm{~g} / \mathrm{day}$ (after parturition up to 60 days in milk) of RPC. Leiva et al., (2015) supplemented 50 and $100 \mathrm{~g}$ of RPC before and after parturition respectively and found no significant effect ( $\mathrm{p}$ $\geq 0.05$ ) on DMI in HF cows. Similar results were also obtained by (Hartwell et al., 2000; Piepenbrink and Overton, 2003; Pinotti et al., 2003). In contrary to this, Zom et al., (2011) reported increased DMI in cows supplemented with RPC. In a study by Sun $e t$ al., (2016), multiparous transition cows were given $15 \mathrm{~g} / \mathrm{d}$ RPC, $15 \mathrm{~g} / \mathrm{d}$ RPM or $15 \mathrm{~g} / \mathrm{dRPC}$ $+15 \mathrm{~g} / \mathrm{d}$ RPM and they found increased postpartum dry matter intake (DMI) (P < 0.05 ), and improved energy balance values in supplemented cows after parturition. Feeding rumen-protected choline (RPC) at the level of $20 \mathrm{~g} /$ buck/day increased $(\mathrm{P}<0.05)$ dry matter intake and feed conversion while water intake was not affected by RPC (Habeeb et al., 2017). Winkler et al., (2015) gave $0.175 \mathrm{~g}$ plant product (green tea extract-95\% and curcuma extract-5\%) per $\mathrm{kg}$ dry matter to each HF cow of treatment group and found no significant difference $(p \geq 0.05)$ in DMI between the groups.

In our experiment, DMI did not vary significantly across the groups. Moreover, it was also found that, addition of RPC and GTE did not affect the palatability and digestibility of the feed, for which it can be added in the feed formulation for better performance. 
Table.1 Effect of RPC and GTE supplementation on fortnightly body weights (kg) of KF cows

\begin{tabular}{|c|c|c|c|c|}
\hline Days & C & T 1 & T 2 & T3 \\
\hline $\mathbf{- 3 0}$ & $439.00 \pm 23.25$ & $442.62 \pm 21.74$ & $440.12 \pm 23.97$ & $444.25 \pm 29.20$ \\
\hline $\mathbf{- 1 5}$ & $449.25 \pm 23.26$ & $455.25 \pm 21.06$ & $450.25 \pm 23.86$ & $455.75 \pm 29.04$ \\
\hline $\mathbf{0}$ & $409.12 \pm 23.38$ & $417.50 \pm 21.34$ & $411.50 \pm 24.42$ & $415.50 \pm 29.02$ \\
\hline $\mathbf{1 5}$ & $399.12 \pm 23.37$ & $409.13 \pm 22.40$ & $404.25 \pm 24.45$ & $404.87 \pm 29.08$ \\
\hline $\mathbf{3 0}$ & $390.25 \pm 23.10$ & $402.13 \pm 22.93$ & $397.25 \pm 24.06$ & $396.62 \pm 29.15$ \\
\hline $\mathbf{4 5}$ & $383.87 \pm 23.40$ & $398.00 \pm 23.00$ & $394.00 \pm 23.88$ & $392.25 \pm 27.91$ \\
\hline $\mathbf{6 0}$ & $381.12 \pm 22.84$ & $395.37 \pm 23.01$ & $392.63 \pm 23.38$ & $390.50 \pm 27.71$ \\
\hline
\end{tabular}

Data represented as mean $\pm \mathrm{SE}$

Table.2 Effect of RPC and GTE supplementation on BCS of KF cows

\begin{tabular}{|c|c|c|c|c|}
\hline Days & C & T1 & T2 & T3 \\
\hline $\mathbf{- 3 0}$ & $3.62 \pm 0.12$ & $3.68 \pm 0.13$ & $3.62 \pm 0.08$ & $3.60 \pm 0.13$ \\
\hline $\mathbf{- 1 5}$ & $3.75 \pm 0.94$ & $3.81 \pm 0.91$ & $3.75 \pm 0.94$ & $3.77 \pm 0.88$ \\
\hline $\mathbf{0}$ & $3.43 \pm 0.11$ & $3.50 \pm 0.01$ & $3.56 \pm 0.11$ & $3.51 \pm 0.08$ \\
\hline $\mathbf{1 5}$ & $3.37 \pm 0.08$ & $3.41 \pm 0.06$ & $3.46 \pm 0.10$ & $3.43 \pm 0.14$ \\
\hline $\mathbf{3 0}$ & $3.26 \pm 0.08$ & $3.37 \pm 0.12$ & $3.37 \pm 0.08$ & $3.37 \pm 0.08$ \\
\hline $\mathbf{4 5}$ & $3.12 \pm 0.12$ & $3.25 \pm 0.13$ & $3.23 \pm 0.16$ & $3.25 \pm 0.09$ \\
\hline $\mathbf{6 0}$ & $3.06 \pm 0.14$ & $3.18 \pm 0.13$ & $3.12 \pm 0.12$ & $3.17 \pm 0.08$ \\
\hline
\end{tabular}

Data represented as mean \pm SE

Table.3 Effect of RPC and GTE supplementation on fortnightly DMI ( $\mathrm{kg} / \mathrm{d})$ of KF cows

\begin{tabular}{|l|l|l|l|l|}
\hline Days & C & T & T 2 & T 3 \\
\hline $\mathbf{- 3 0}$ & $11.06 \pm 0.29$ & $11.18 \pm 0.29$ & $10.93 \pm 0.25$ & $11.12 \pm 0.37$ \\
\hline $\mathbf{- 1 5}$ & $10.18 \pm 0.20$ & $10.31 \pm 0.26$ & $10.37 \pm 0.24$ & $10.43 \pm 0.34$ \\
\hline $\mathbf{0}$ & $8.81 \pm 0.35$ & $8.93 \pm 0.25$ & $8.77 \pm 0.27$ & $8.65 \pm 0.31$ \\
\hline $\mathbf{1 5}$ & $11.18 \pm 0.63$ & $11.31 \pm 0.31$ & $11.50 \pm 0.36$ & $11.68 \pm 0.49$ \\
\hline $\mathbf{3 0}$ & $12.42 \pm 0.78$ & $12.81 \pm 0.31$ & $12.68 \pm 0.44$ & $12.87 \pm 0.33$ \\
\hline $\mathbf{4 5}$ & $12.75 \pm 0.59$ & $13.31 \pm 0.26$ & $13.37 \pm 0.38$ & $13.51 \pm 0.29$ \\
\hline $\mathbf{6 0}$ & $13.46 \pm 0.39$ & $13.75 \pm 0.28$ & $13.87 \pm 0.39$ & $14.08 \pm 0.26$ \\
\hline
\end{tabular}

Data represented as mean $\pm \mathrm{SE}$

In conclusion, the fortnightly average body weights, BCS and DMI did not differ significantly from control animals with feeding of RPC and GTE. So, supplementing RPC and GTE in combination can be a better option to enhance production performances, antioxidant capacity, majorly provided by GTE, in transition cows.

\section{References}

Ahmed, S. T., Lee, J. W., Mun, H. S. and Yang, C. J. 2015. Effects of supplementation with green tea by-products on growth performance, meat quality, blood metabolites and immune cell proliferation in goats. $J$. 
Anim. Physiol. Anim. Nutr., 99(6): 1127-1137.

Ardalan, M., Dehghan-Banadaky, M. and Kamran R. 2010. Milk yield persistency and its relationship with health problems in Holstein dairy cows supplemented with different levels of ruminally protected methionine and choline. Archiv Tierzucht., 53(3): 266-276.

Baruselli, P. S., Barnabe, V. H., Barnabe, R. C., Visintin, J. A., Molero-Filho, J. R. and Porto, R. 2001. Effect of body condition score at calving on postpartum reproductive performance in buffalo. Buffalo J., 17(1): 53-66.

Bauman, D. E. and Currie, W. B. 1980. Partitioning of nutrients during pregnancy and lactation: A review of mechanisms involving homeostasis and homeorhesis. J. Dairy Sci., 63: 1514-1529.

Bell, A. W., Slepetis, R. and Ehrhardt, U. A. 1995. Growth and Accretion of Energy and Protein in the Gravid Uterus During Late Pregnancy in Holstein Cows. J. Dairy Sci., 78(9): 1954-1961.

Bertics, S. J., Grummer, R. R., CardornigaValino, C. and Stoddard, E. E. 1992. Effect of prepartum dry matter intake on liver triglyceride concentration and early lactation. J. Dairy Sci., 75: 1914.

Chung, Y. H., Cassidy, T. W., Girard, I. D., Cavassini, P. and Varga, G. A. 2005. Effects of rumen protected choline and dry propylene glycol on feed intake and blood metabolites of Holstein dairy cows. J. Dairy Sci., 88 (1): 61.

Davidson, S., Hopkins, B. A., Odle, J., Brownie, C., Fellner, V. and Whitlow, L. W. 2008. Supplementing limited methionine diets with rumen-protected methionine, betaine and choline in early lactation Holstein cows. J Dairy Sci., 91: 1552-1559. de Ondarza, M. B., Emanuele, S. and Putnam, D. 2007. Effect of rumen protected choline (Reashure) supplemented to high producing cows on milk production, milk components, and intake. J. Dairy Sci., 90(Suppl. 1): 353.

Elek, R., Newbold, J. R., Gaal, I., Wagner, L. and Husveth, F. 2008. Effects of rumen protected choline supplementation on milk production and choline supply of periparturient dairy cows. Animal., 2: 1595-1601.

Erdman, R. A. and Sharma, B. K. 1991. Effect of dietary rumen-protected choline in lactating dairy cows. $J$. Dairy Sci., 74: 1641-1647.

Grant, R. J. and Albright, J. L. 1995. Feeding behavior and management during the transition period in dairy cattle. $J$. Anim. Sci., 73: 2791.

Grummer, R. R. 2008. Nutritional and management strategies for the prevention of fatty liver in dairy cattle. Vet. J., 176(1): 10-20.

Habeeb, A. A. M., Gad, A. E., Atta, M. A. A. and Abdel-Hafez, M. A. M. 2017. Evaluation of rumen-protected choline additive to diet on productive performance of male Zaraibi growing goats during hot summer season in Egypt. Trop. Anim. Health. Prod., 49(6): 1107-1115.

Hartwell, J. R., Cecava, M. J. and Donkin, S. S. 2000. Impact of dietary rumen undegradable protein and rumenprotected choline on intake, peripartum liver triacylglyceride, plasma metabolites and milk production in transition dairy cows. $J$. Dairy Sci., 83: 2907-2917.

Hayirli, A., Grummer, R. R., Nordheim, P., Crump, D. K., Beede, M. J., VandeHaar, M. J. and Kilmer, L. H. 1998. A mathematical model for describing dry matter intake of 
transition dairy cows. J. Dairy Sci., 81: 296.

Hodgson, A. B., Randell, R. K., Boon, N., Garczarek, U., Mela, D. J., Jeukendrup, A. E. and Jacobs, D. M. 2013. Metabolic response to green tea extract during rest and moderateintensity exercise. J. Nutr. Biochem., 24(1): 325-334.

Hossain, M. E., Ko, S. Y. and Yang, C. J. 2012. Dietary supplementation of green tea by-products on growth performance, meat quality, blood parameters and immunity in finishing pigs. J Med Plant Res., 6(12): 24582467.

Janovick Guretzky, N. A., Carlson, D. B., Garrett, J. E. and Drackley, J. K. 2006. Lipid Metabolite Profiles and Milk Production for Holstein and Jersey Cows Fed Rumen-Protected Choline During the Periparturient Period. J. Dairy Sci., 89: 188-200.

Kaneko, K., Yamasaki, K., Tagawa, Y., Tokunaga, M., Tobisa, M. and Furuse, M. 2001. Effects of dietary Japanese green tea powder on growth, meat ingredient and lipid accumulation in broilers. Jpn. Poult. Sci., 38(5): J77$\mathrm{J} 85$.

Kertz, A. F., Reutzel, L. F. and Thomson, G. M. 1991. Dry matter intake from parturition to mid-lactation. J. Dairy Sci., 74: 2290.

Leiva, T., Cooke, R. F., Brandao, A. P., Marques, R. S. and Vasconcelos, J. L. M. 2015. Effects of rumen-protected choline supplementation on metabolic and performance responses of transition dairy cows. J. Anim Sci., 93(4): 1896-1904.

NRC, 2001. National Research Council. Nutrient requirements of dairy cattle. 7th ed. Natl. Acad. Sci., Washington, DC

Oelrichs, W. A., Lucy, M. C., Kerley, M. S. and Spain, J. N. 2004. Feeding soybeans and rumen-protected choline to dairy cows during the periparturient period and early lactation. J. Dairy Sci., 87: 344.

Pandurang, P. S. 2012. Supplementing rumen protected choline to dairy cattle during transition period: Effect on milk production and reproductive performance (Doctoral dissertation, NDRI, Karnal).

Piepenbrink, M. S. and Overton, T. R. 2003. Liver metabolism and production of cows fed increasing amounts of rumen-protected choline during the periparturient period. J. Dairy Sci., 86: 1722-1733.

Pinotti, L., Baldi, A., Politis, I., Rebucci, R., Sangalli, L. and Dell'Orto, V. 2003. Rumen protected choline administration to transition cows: effects on milk production and vitamin E status. J. Vet. Med., 50: 18-21.

Robinson, P. H. and Garrett, J. E. 1999. Effect of yeast culture (Saccharomyces cerevisiae) on adaptation of cows to post partum diets and on lactational performance. J. Anim. Sci., 77: 988.

Roche, J. F. 2006. The effect of nutritional management of the dairy cow on reproductive efficiency. Anim. Reprod. Sci., 96(3-4): 282-296.

Sayama, K., Lin, S., Zheng, G. and Oguni, I. 2000. Effects of green tea on growth, food utilization and lipid metabolism in mice. In vivo., 14(4): 481-484.

Sharma, B. K. and Erdman, R. A. 1988. Abomasal infusion of choline and methionine with or without 2-amino2-methyl-1-propanol for lactating dairy cows. J. Dairy Sci., 71: 2406-2411.

Sheikh, F. A., Kewalramani, N., Thakur, S. S. and Mir, I. A. 2014. Effect of supplementation of rumen protected methionine-lysine and choline on milk production in crossbred cows. Indian 
J. Anim. Nutr., 31(2): 148-151.

Sun, F., Cao, Y., Cai, C., Li, S., Yu, C. and Yao, J. 2016. Regulation of nutritional metabolism in transition dairy cows: energy homeostasis and health in response to post-ruminal choline and methionine. PloS one., 11(8): e0160659.

Tan, C. Y., Zhong, R. Z., Tan, Z. L., Han, X. F., Tang, S. X., Xiao, W. J., Sun, Z.H. and Wang, M. 2011. Dietary inclusion of tea catechins changes fatty acid composition of muscle in goats. Lipids., 46(3): 239-247.

Taylor, V. J., Beever, D. E. and Wathes, D. C. 2004. Physiological adaptations to milk production that affect the fertility of high yielding dairy cows. In: Kebreab, E; Mills, J. and Beever, D. eds. Dairying: using science to meet consumers' needs. Nottingham: Nottingham University Press, pp. 3771.

Winkler, A., Gessner, D. K., Koch, C., Romberg, F. J., Dusel, G., Herzog, E.,
Most, E., Most, E. and Eder, K. 2015. Effects of a plant product consisting of green tea and curcuma extract on milk production and the expression of hepatic genes involved in endoplasmic stress response and inflammation in dairy cows. Arch Anim Nutr., 69(6): 425-441.

Zahra, L. C., Duffield, T. F., Leslie, K. E., Overton, T. R., Putnam, D. and LeBlanc, S. J. 2006. Effects of rumenprotected choline and monensin on milk production and metabolism of periparturient dairy cows. J. Dairy Sci., 89: 4808-4818.

Zom, R.L.G., van Baal, J., Goselink, R. M. A., Bakker, J. A., de Veth, M. J. and van Vuuren, A. M. 2011. Effect of rumen-protected choline on performance, blood metabolites and hepatic triacylglycerols of periparturient dairy cattle. J. Dairy Sci., 94: 4016-4027.

\section{How to cite this article:}

Acharya, P., S.S. Lathwal, B. Moharana, N.M. Patnaik and Thul, M. 2019. Analysing the Effect of Supplementing Rumen Protected Choline with Green Tea Extract in Transition Karan Fries Cows. Int.J.Curr.Microbiol.App.Sci. 8(02): 2432-2440. doi: https://doi.org/10.20546/ijcmas.2019.802.283 